\title{
ANALYZING SURFACE ROUGHNESS MODELS DERIVED BY SAR AND DEM DATA AT GEOTHERMAL FIELDS
}

\author{
TAHJUDIL WITRA ${ }^{1,2}$, ASEP SAEPULOH ${ }^{1,2}$, AGUNG BUDI HARTO ${ }^{1,2}$, KETUT \\ WIKANTIKA ${ }^{1,2}$
}

1. Faculty of Earth Sciences and Technology, Institut Teknologi Bandung (ITB), JL. Ganesha No.10, Bandung, Jawa Barat, Indonesia, 40132, Email: tahjudil.witra@gmail.com

2. Center for Remote Sensing, Institut Teknologi Bandung (ITB), Jalan Ganesha 10, Bandung, 40132, Jawa Barat, Indonesia.

\begin{abstract}
Sari - Kekasaran permukaan merupakan unsur fisik yang digunakan dalam berbagai aplikasi, misalnya untuk analisis hidrologi, erosivitas batuan, dan identifikasi manifestasi permukaan geotermal. Kekasaran permukaan dihitung dengan menggunakan alat pin-meter. Alat digunakan untuk menghitung kekasaran permukaan tanah yang berasosiasi dengan fragmen material di permukaan tanah. Pengukuran menggunakan pin-meter masih memiliki kemungkinan kesalahan yang berasal dari efek undulasi topografi, sehingga diperlukan detrending profil untuk mengurangi efek undulasi tersebut. Pada makalah ini, kami menggunakan data Synthetic Aperture Radar (SAR) Sentinel-1A dan Digital Elevation Model (DEM) SRTM untuk mengevaluasi efek undulasi topografi setelah dilakukan detrending. Model kekasaran permukaan yang diperoleh ditargetkan mendekati fragmen material di permukaan tanah. Lokasi penelitian yang dipilih yaitu di daerah sekitar Gunung Wayang-Windu dan Patuha. Pembuatan model awal kekasaran permukaan dengan data Sentinel-1A dilakukan dengan memanfaatkan nilai backscattering coefficient dan local incidence angle. Untuk mengetahui efektifitas detrending, kami memodelkan kekasaran permukaan menggunakan data DEM dengan menghitung Root Mean Square (RMS) untuk setiap grid dengan ukuran 19×19 piksel. Kedua model tersebut kemudian dikorelasikan terhadap data kekasaran permukaan lapangan dari pin-meter dan dihitung besarnya koefisien determinasi $\left(\mathrm{R}^{2}\right)$. Model dari data Sentinel-1A memiliki nilai $\mathrm{R}^{2}$ sebesar 0.1130 lebih besar daripada model kekasaran dari DEM sebesar 0.060. Hal ini menunjukan bahwa data kekasaran pin-meter yang di-detrending terhindar dari efek undulasi topografi. Model kekasaran permukaan dari data Sentinel-1A digunakan untuk pengidentifikasian manifestasi permukaan berbasis nilai $\mathrm{pH}$ tanah. Analisis dilakukan berdasarkan pengukuran lapangan dan pola scatter plot. Berdasarkan model yang dipilih, secara umum pada zona manifestasi geotermal memiliki hubungan berbanding terbalik antara $\mathrm{pH}$ dengan model kekasaran.
\end{abstract}

Kata kunci: Sentinel-1A, DEM, geotermal, kekasaran permukaan, pin-meter

\begin{abstract}
Surface roughness is a physical property which is used in many applications such as hydrological analyses, erosivity of rocks, and identification of geothermal surface manifestations. In this study, the surface roughness was calculated by a pin-meter. This tool is expected be able to measure the fragmental size at ground surface. However, there is a possibility that the tool still has some errors from the effect of topography undulation. In previous research, detrending method was used to minimise the topographical effect in the measured surface roughness. In this paper, we used Synthetic Aperture Radar (SAR) data from Sentinel-1A, and Digital Elevation Model (DEM) SRTM to evaluate the effectiveness of detrending method of pin-meter. Therefore, the measured surface roughness originated solely from fragmental materials. The selected research areas were Wayang Windu and Patuha geothermal field in Indonesia. Modelling the surface roughness by Sentinel-1A image was conducted by utilising backscattering coefficient and local incidence angle. While surface roughness model from DEM is formed by the Root mean square (RMS) for each grid with the optimum size $19 \times 19$ pixels. Both models were compared to pin-meter data which have been detrended. Then, the comparison was analyzed based on determination correlation value $\left(R^{2}\right)$. Surface roughness model derived by Sentinel-1A produced $R^{2}$ about 0.1130 higher than DEM about 0.060. It might indicate that the surface roughness measured by the pin-meter following detrending process is free from the effect of topography undulation. Then, surface roughness model derived by Sentinel-1A data was used to identify surface manifestation. Analysis was performed based on $\mathrm{pH}$ measurement at field and scatter plot pattern. According to the selected model, the surface roughness at geothermal surface manifestation zones are inversely proportional to the soil $\mathrm{pH}$.
\end{abstract}

Keywords: Sentinel-1A, DEM, geothermal, surface roughness, pin-meter 


\section{INTRODUCTION}

Based on Hajnsek (2001), the methods for estimating surface roughness are developed since 50 years ago. The methods are divided two main categories: two- and threedimensionals. The often-used method is two dimensions (Hajnsek, 2001). The twodimensional method is formed mechanically by using needles on board. The height difference between needles presents surface profile. This tool is called pin-meter. In this paper, the surface roughness is defined as a variance of earth surface elevation above the horizontal line (Saepuloh et al., 2015). Surface roughness explains about fragments on the ground surface. Thus, the ground surface must be free from topographic effects. Therefore, this research was aimed to clarify that the pinmeter data is independent from topographic effect by utilizing a surface roughness model from Polarimetric Synthetic Aperture Radar (PolSAR) and Digital Elevation Model (DEM) data.

SAR technology with long wavelength is superior to detect target at surface and near surface regardless atmospheric condition such as cloud and water vapor. SAR satellite transmits microwave energy and receives the backscattering signals. The backscattering signals are controlled by surface roughness, dielectric permittivity, and magnetic permeability of ground surface. The primary factor influenced backscattering is surface roughness which is related to rock types (Saepuloh et al. 2016). The PolSAR image used in this paper is Sentinel-1A in C-band frequency equivalent to wavelength $5.6 \mathrm{~cm}$. In addition, the Shuttle Radar Topography Mission (SRTM) $30 \mathrm{~m}$ DEM was used to generate surface roughness related to topographic undulations. The DEM surface roughness was modeled to confirm that the topographic undulation was excluded in the surface roughness measured by pin-meter and PolSAR data.

\section{DATA AND METHODOLOGY}

\subsection{Data}

The study area was located at Mts. WayangWindu and Patuha, West Java, Indonesia and presented by Figure 1. There are four data used in this study: surface roughness at field obtained by a pin-meter, Sentinel-1A SAR, SRTM DEM $30 \mathrm{~m}$, and soil pH data. The pinmeter size was $30 \mathrm{~cm}$ width containing 60 pins. The 269 points were measured at the field by the pin-meter with three directions: N-S, W-E, and topographic slope (N-E). The detrending and interleaving techniques were applied to obtain accurate surface roughness (Saepuloh et al., 2016). Sentinel-1A SAR image used in this study is in Ground Range Detected (GRD) level with interferometric wide swath acquisition type. It was acquired at $2^{\text {nd }}$ February 2016 on descending orbit with the incidence angle between $29.1^{\circ}$ and $46.0^{\circ}$ in near and far range, resepectively. The DEM SRTM $30 \mathrm{~m}$ was also used for generating surface roughness model related to topographic undulation. The measured soil $\mathrm{pH}$ data at 41 locations were used to identify the geothermal surface manifestation. The low $\mathrm{pH}$ about 1-4 was assumed to correlate with hydrothermal fluids.

\subsection{Methodology \\ 2.2.1 Surface Roughness Quantification}

Quantifying surface roughness is conducted by measuring height different among pins. The quantified surface roughness is root mean square (RMS) of heights. Detrending and interleaving are applied to result in the pinmeter reading. According to Saepuloh et al. (2016), the RMS height $H_{0}$ was calculated for the three directions as follows:

$H_{0}(\zeta)=\sqrt{\left[\frac{1}{n} \sum_{i=1}^{n}\left(z\left(x_{i}\right)-\bar{z}\right)^{2}\right]}$

Where $n$ is count of pins (=60), $z\left(x_{i}\right)$ is the height of the surface at the point $x_{i}, \bar{z}$ is mean height of the surface within the profile, and $\zeta$ is the pin-meter direction (N-S, E-W, and N-E). For achieving more accurate RMS height, we combined all RMS values and termed as RMS heigh total $\mathcal{H}_{0}$ as follows: 


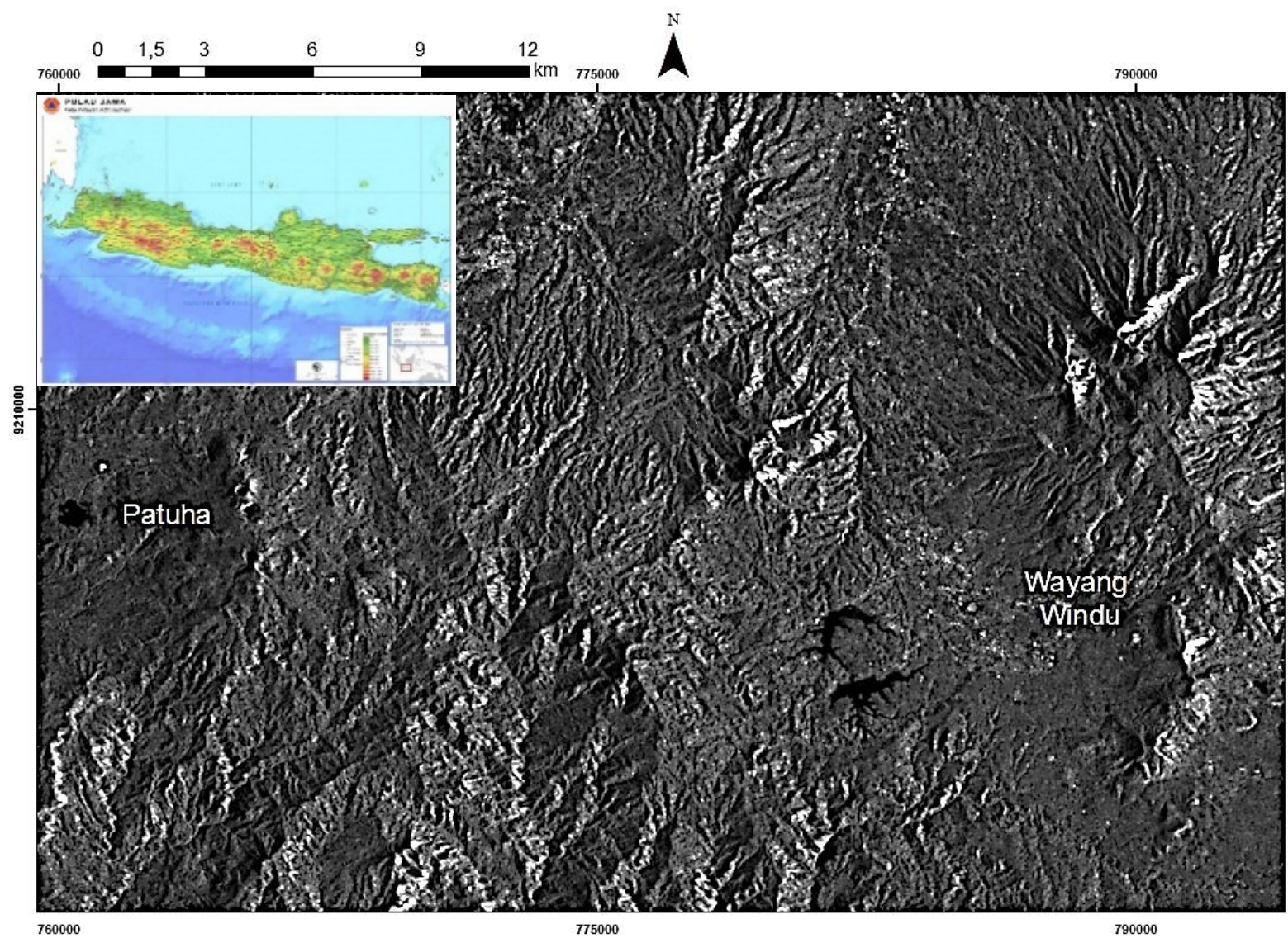

Figure 1. Location of study area at Mt. Wayang- Windu and Patuha overlaid on Sentinel-1A image with VV polarization.

$$
\mathcal{H}_{0}=\sqrt{\frac{1}{k} \sum_{j=1}^{k}\left(H_{O_{j}}\right)^{2}}
$$

Where $k$ is number of measurement direction (=3), $H_{0_{j}}$ is RMS height of measurement direction $j^{\text {th }}$.

\subsubsection{Surface Roughness Model by Sentinel- \\ $1 \mathrm{~A}$}

Sentinel-1A level GRD has two types of polarisation (VH and VV). Each of type was extracted to obtain the backscattering coefficient. An open source software Sentinel Application Platform (SNAP) was used to calibrate, correct, and transform the Single Look Complex (SLC) to Multi Look Image (MLI) of Sentinel-1A SAR data from European Space Agency (ESA). There are four steps to obtain backscattering intensity image from MLI: range Doppler terrain correction, speckle filter, thermal noise removal, and radiometric calibration. The range Doppler terrain correction was used for correcting the geometry of topographical distortion, speckle filtering for reducing speckle noises, and thermal noise removal for correcting distortion effect from thermal especially for low scatter region like the sea and lake. The radiometric calibration was used for correcting and extracting backscattering coefficient as follows (Miranda and Meadows, 2015):

$$
\sigma_{d b}^{0}=10 \cdot \log _{10}\left(\frac{D N^{2}}{A_{\sigma}^{2}}\right)
$$

Where $\sigma_{d b}^{0}$ is backscattering coefficient, $D N$ is digital number, and $A_{\sigma}$ is look up table to transform radar reflectance to backscattering. An initial model served as an estimation of surface roughness was calculated for each polarised type as follows (Saepuloh et al., 2015): 
$h_{0}(\eta \zeta)=\lambda \sqrt{-\frac{1}{60} \ln \left(1-\frac{10^{\left(0.1 x \sigma^{0} \eta \zeta\right)}}{0.04 \cos \theta_{i}}\right)}$

where $h_{0}$ is an initial model of surface roughness, $\eta \zeta$ is polarized type either in $\mathrm{H}$ and $\mathrm{V}, \lambda$ is wavelength $(=5.6 \mathrm{~cm}), \sigma_{\eta \zeta}^{0}$ is backscattering coefficient based on polarized type, and $\theta_{i}$ is local incidence angle. We use linear fitting method to obtain correlation determination $R^{2}$ between surface roughness from model and pin-meter. We tried to generate others model which able to reach high $R^{2}$ value using combination of $\mathrm{VV}, \mathrm{VH}$, and $\theta_{i}$.

\subsubsection{Surface Roughness Model by DEM}

The SRTM DEM $30 \mathrm{~m}$ is a potential source to calculate the surface roughness model related to topographic undulation. The model was calculated using various window sizes. There were ten window sizes from $3 \times 3$ to $21 \times 21$ pixels. The illustration of this process was presented by Figure 2. The surface roughness model from SRTM DEM 30 m was calculated as follows:

$$
H_{0 D E M}=\sqrt{\left[\frac{1}{n} \sum_{i=1}^{n}\left(z\left(x_{i}\right)-\bar{z}\right)^{2}\right]}
$$

where $H_{0 D E M}$ is surface roughness model related to topographic undulation, $n$ is window size, $z\left(x_{i}\right)$ is value of $i^{\text {th }}$ pixel, and $\bar{z}$ is mean of all pixel value in the window. Linear fitting method was used to obtain $R^{2}$ between $H_{0}$ DEM and $H_{0}$. Table 3 and Figure 4 show the $R^{2}$ between $H_{0 D E M}$ and $H_{0}$.

\subsubsection{Identification of Geothermal Surface Manifestation}

The surface roughness model from Sentinel$1 \mathrm{~A}$ and DEM were used to obtain the optimum model presented by spatial agreement with ground $\mathrm{pH}$. Based on the model, the geothermal manifestation was identified by location and pattern of scatter plot. $\mathrm{PH}$ and surface roughness model are plotted to identify the spatial distribution of geothermal manifestation.

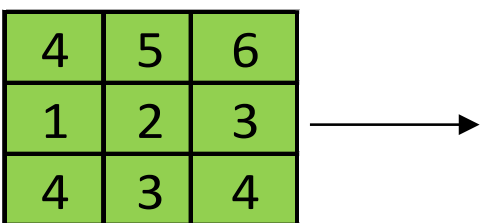

\section{Algor ithm}

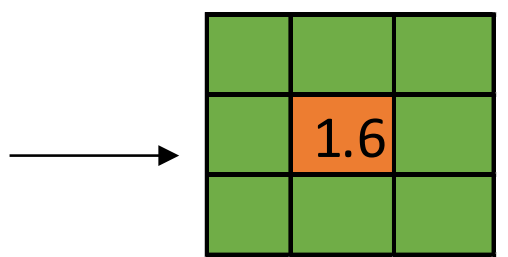

Figure 2. Illustration of surface roughness calculation using DEM SRTM $30 \mathrm{~m}$ using window size $3 \times 3$.

Table 1. The high $R^{2}$ of surface roughness model based on Sentinel-1A data.

\begin{tabular}{lrrrr} 
Model & N-S & W-E & N to E & RMS Total \\
\hline model inisial VV & 0.0023 & 0.0157 & 0.0253 & 0.0141 \\
Model inisial VH & 0.0010 & 0.0091 & 0.0016 & 0.0075 \\
Model M6 & 0.0036 & 0.0163 & 0.0035 & 0.0150 \\
Model M1 & 0.0291 & 0.0745 & 0.0148 & 0.0710 \\
Model M4 & 0.0458 & 0.0764 & 0.0308 & 0.0796 \\
Model M5 & 0.0521 & 0.1130 & 0.0238 & 0.1110 \\
\hline
\end{tabular}

Tabel 2. Mathematical model of surface roughness with high $R^{2}$ based on Sentinel-1A data. 


\begin{tabular}{|c|c|c|}
\hline No & Label & Equation \\
\hline 1 & M6 & $h_{0 V V} \times h_{0 V h}$ \\
\hline 2 & M1 & $10\left(h_{0 V V} x h_{0 V h}\right)^{2} \times \tan \left(\theta_{i}\right)$ \\
\hline 3 & M4 & $\left(h_{0 V V} x h_{0 V h}\right)^{3 / 2} \times \tan \left(\left(\theta_{i}\right)^{\frac{3}{2}}\right)$ \\
\hline 4 & M5 & $\left(h_{0 V V^{\frac{5}{2}}}+h_{0 V h}{ }^{5 / 2}\right)^{3 / 2} \times \tan \left(\left(\theta_{\mathrm{i}}\right)^{\frac{3}{2}}\right) \times \log \left(\theta_{\mathrm{i}}\right) \times 1000$ \\
\hline
\end{tabular}

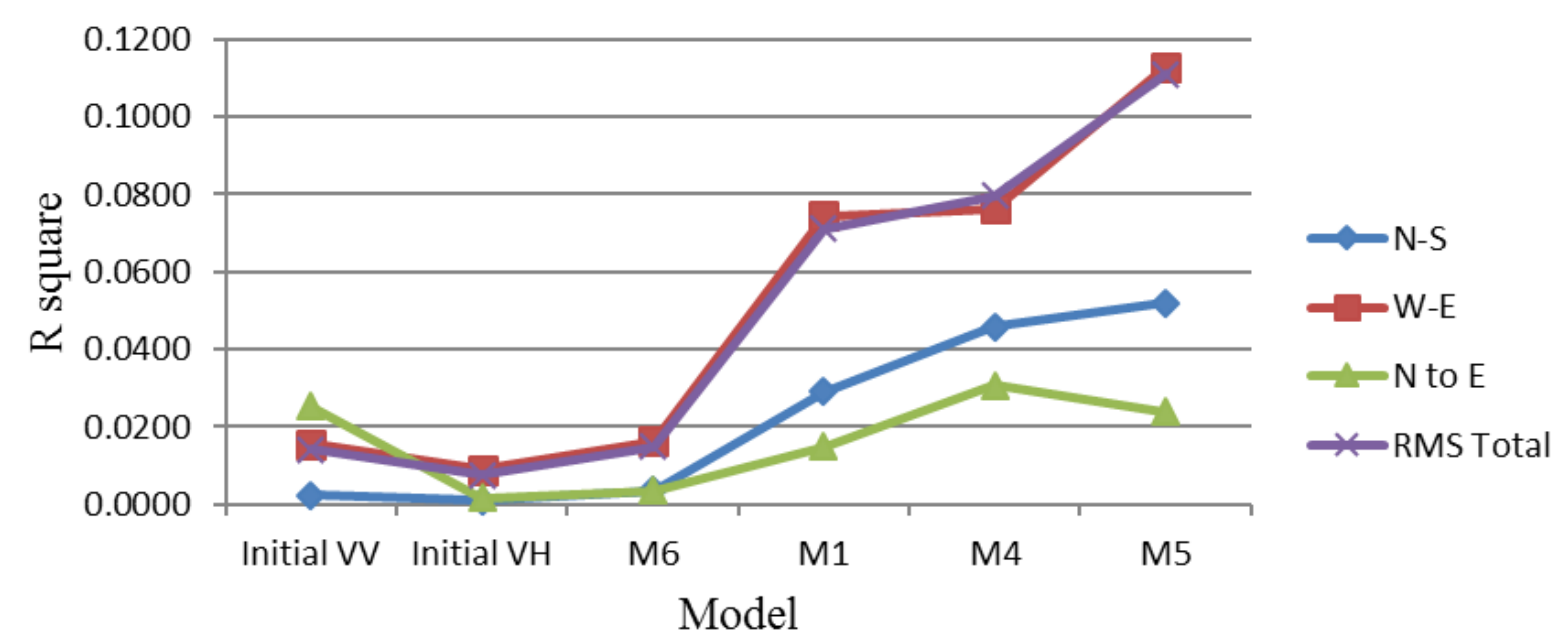

Figure 3. The influence of measurement direction to the surface roughness model related to topographic undulation showed that W-E measurement is the highest $R^{2}$ value almost for all models.

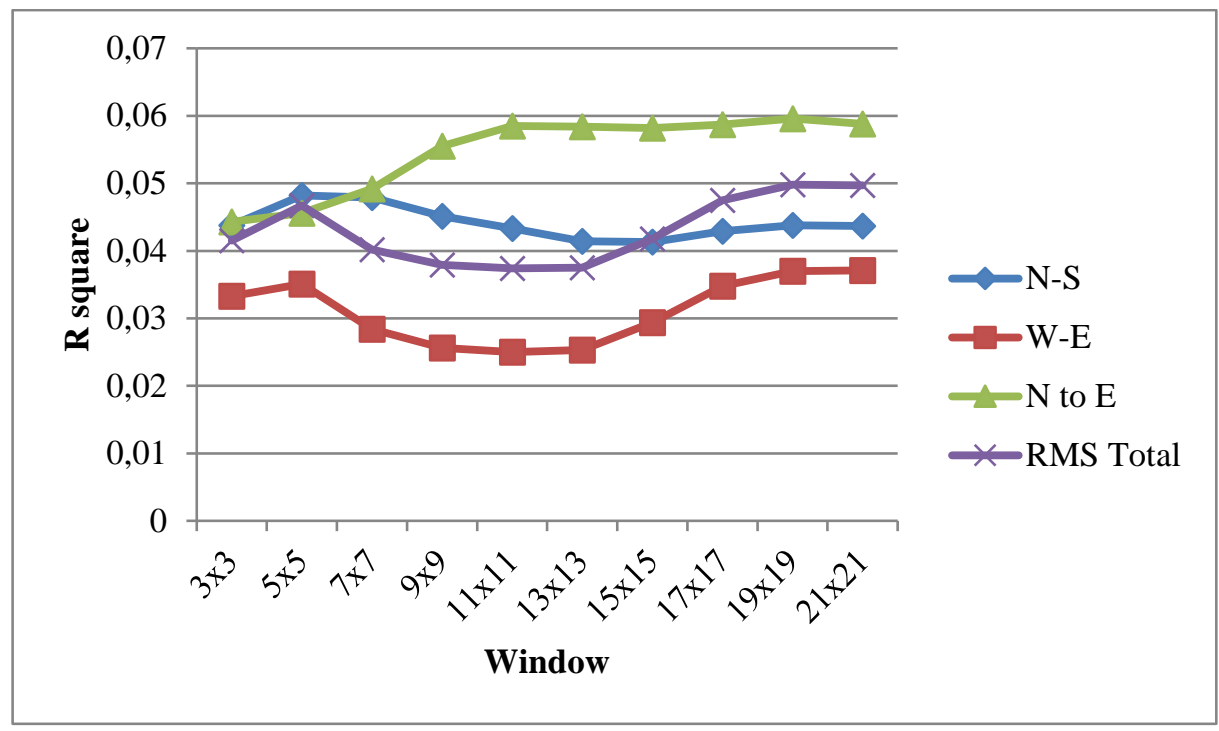

Figure 4. The effect of window size to surface roughness from pin-meter showed variation of $R^{2}$.

Table 3. The variation of $R^{2}$ for different window size between surface roughness derived 
by DEM SRTM $30 \mathrm{~m}$ and pin-meter.

\begin{tabular}{lllllrrrrrr}
\hline & $3 \times 3$ & $5 \times 5$ & $7 \times 7$ & $9 \times 9$ & $11 \times 11$ & $13 \times 13$ & $15 \times 15$ & $17 \times 17$ & $19 \times 19$ & $21 \times 21$ \\
\hline N-S & 0.044 & 0.048 & 0.048 & 0.045 & 0.043 & 0.041 & 0.041 & 0.043 & 0.044 & 0.044 \\
W-E & 0.033 & 0.035 & 0.028 & 0.026 & 0.025 & 0.025 & 0.029 & 0.035 & 0.037 & 0.037 \\
N to E & 0.044 & 0.046 & 0.049 & 0.056 & 0.059 & 0.058 & 0.058 & 0.059 & 0.060 & 0.059 \\
RMS & & & & & & & & & & \\
Total & 0.042 & 0.047 & 0.040 & 0.038 & 0.037 & 0.038 & 0.042 & 0.048 & 0.050 & 0.050 \\
\hline
\end{tabular}

\section{RESULTS}

\subsection{Surface Roughness Model}

Table 1 shows the highest $R^{2} \quad(=0.113)$ generated using M5 model from Sentinel-1A image which is used to generate surface roughness by SAR. The calculated mathematical models of surface roughness are listed in Table 2. The Figure 3 illustrates the trend of $R^{2}$ for each model. The Table 3 and Figure 4 shows the $R^{2}$ result of for surface roughness model from DEM SRTM $30 \mathrm{~m}$. The $R^{2}$ of surface roughness model from Sentinel$1 \mathrm{~A}(=0.113)$ is higher than DEM SRTM $30 \mathrm{~m}$ $(=0.060)$. Therefore, the M5 model was predicted as the optimum model to identify the geothermal surface manifestations. Figure 5 shows the roughness model on geothermal manifestations and the surrounding area based on M5 model.

\subsection{Geothermal Surface Manifestation}

Scatter-plot identification of geothermal surface manifestations at Mts. Wayang-Windu and Patuha based on surface roughness model is depicted in Figure 6. Figure 6a shows a correlation for all data that $\mathrm{pH}$ at geothermal manifestation inversely proportional to the surface roughness model generally. Figure $\mathbf{6 b}$ shows correlation based on location at Mts. Wayang-Windu and Patuha. There are two classes in this figure presented by Figure $\mathbf{6 b}$. Figure 6c shows the correlation based on the pattern of scatter plot data which produces three groups while the Figure 7 presents its model spatially. Among these groups, two of them are directly proportional between $\mathrm{pH}$ and M5 and the last one is inversely proportional. These identifications were presented by similarity between the selected model and $\mathrm{pH}$ relating to some parameter (location and $\mathrm{pH}$ ).

\section{CONCLUSION}

The surface roughness derived by pin-meter after detrending and interleaving processes could reduce influence of topographic undulation effect. It was confirmed by correlation determination $R^{2}$ that surface roughness model derived by Sentinel-1A is higher than DEM SRTM $30 \mathrm{~m}$. The optimum Sentinel-1A surface roughness model was obtained by the incorporating $\mathrm{VV}$ and $\mathrm{VH}$ polarization type and local incidence angle. The local incidence angle contributed significantly to improving the correlation. According to the obtained model, we observed that surface roughness at geothermal surface manifestation is inversely proportional to the soil $\mathrm{pH}$. Further study is necessary to separate surface roughness mode to classify geothermal surface manifestation type. 


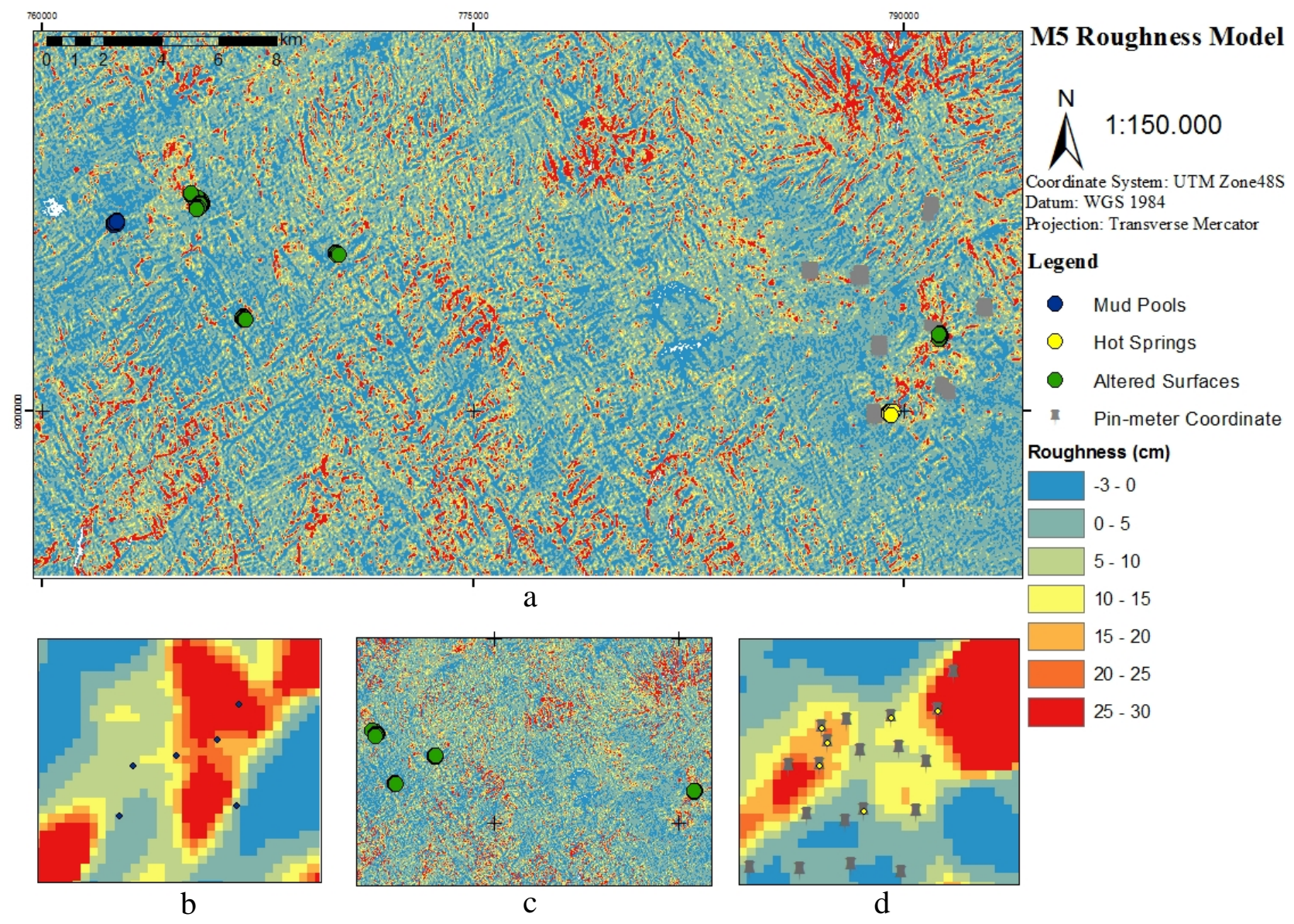

Figure 5. M5 surface roughness model derived by Sentinel-1A data and location of field measurements using pin-meter (a), spatial distribution of geothermal surface manifestation including mud pools (b), altered surfaces (c), hot springs (d).

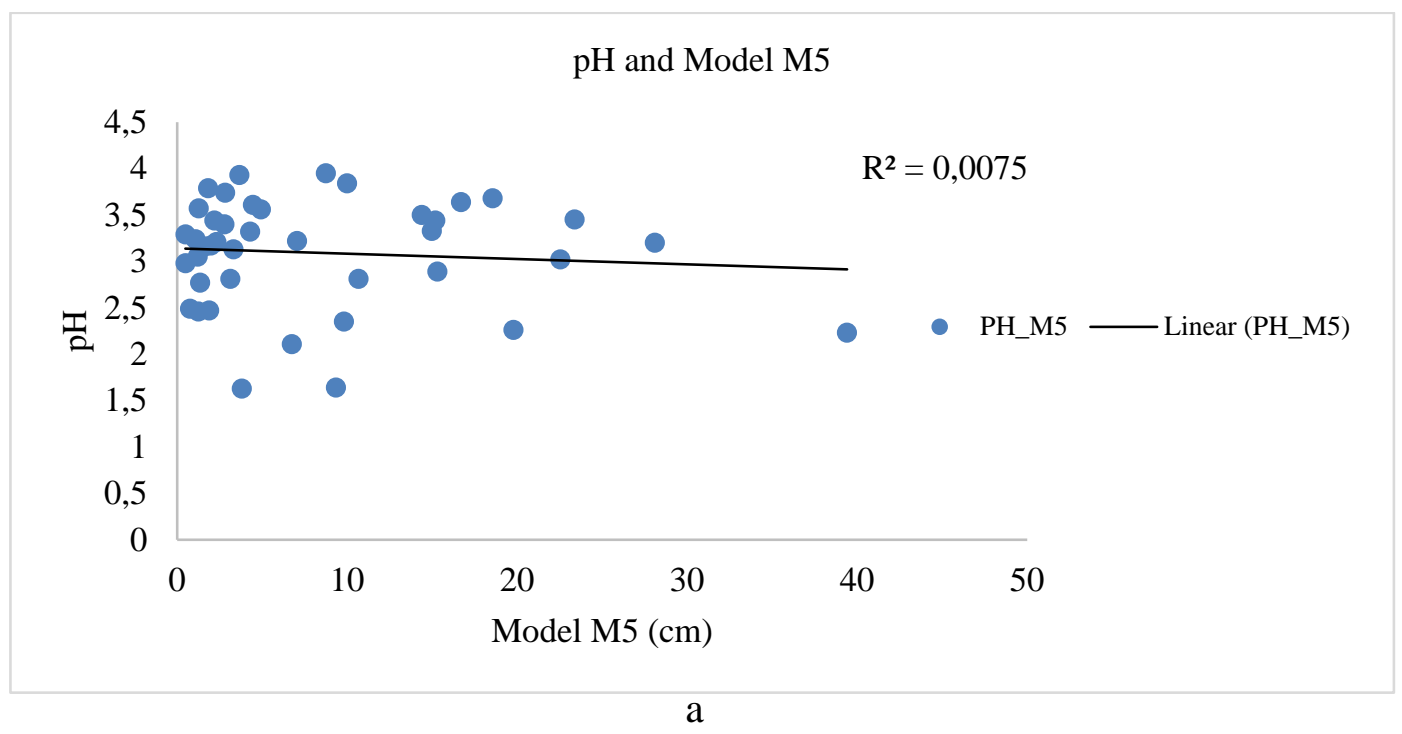


pH based on Location

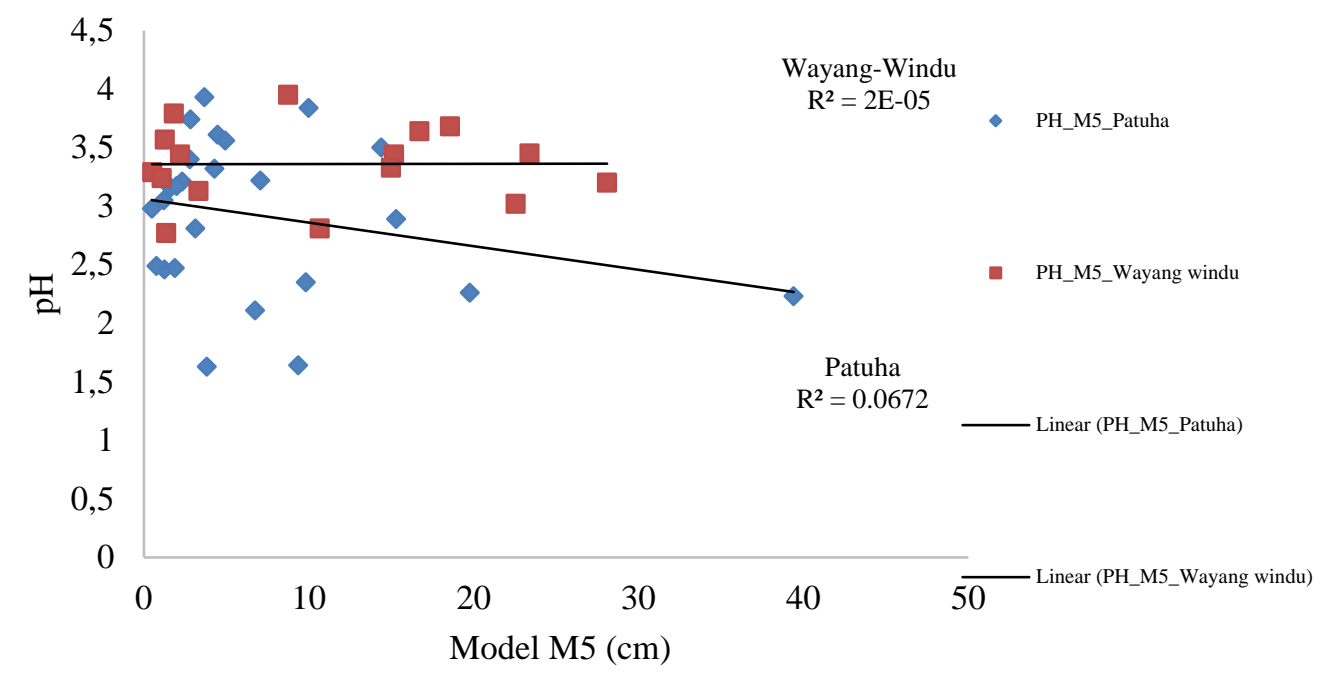

b

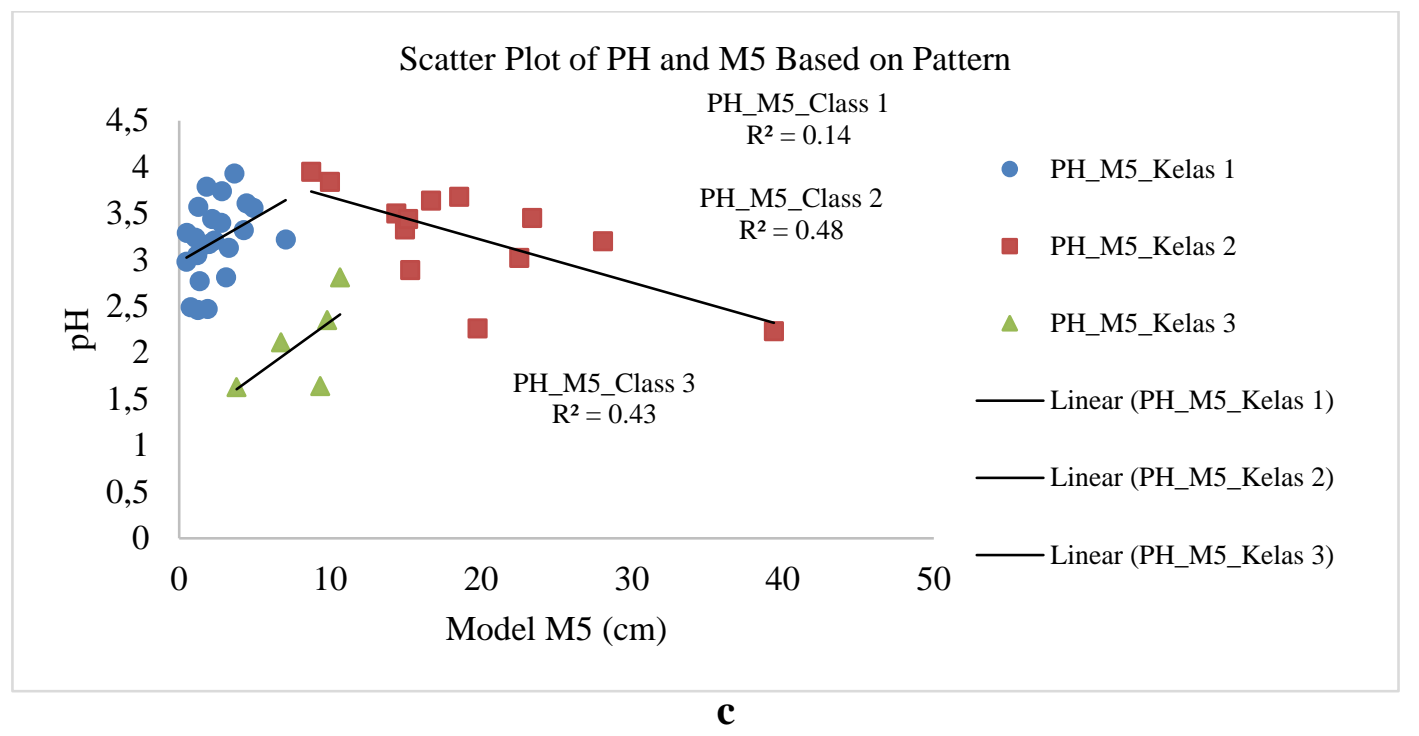

Figure 6. Scatter plot classification of all collected field data (a), location (b), and pattern (c). 


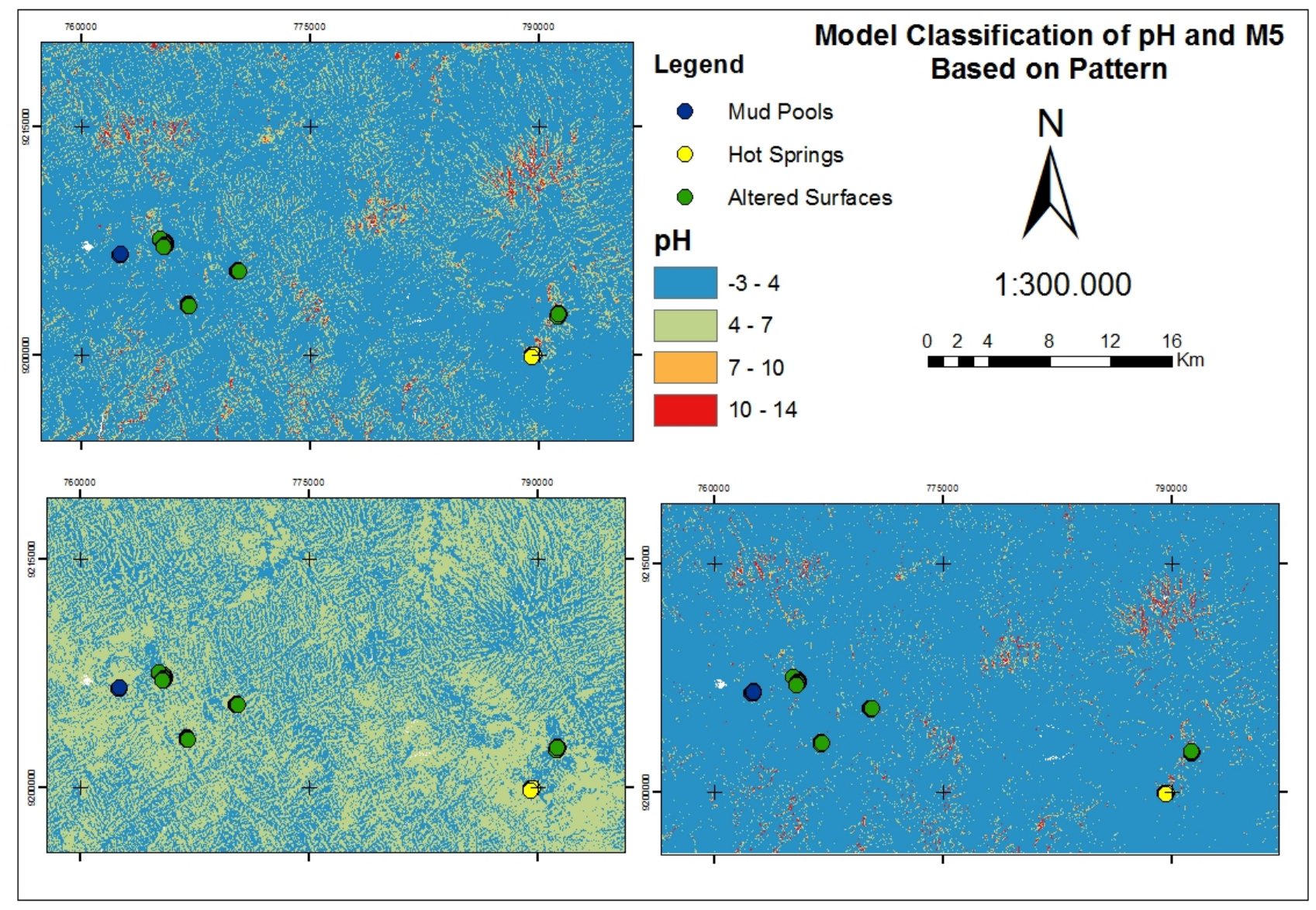

Figure 7. Classification map of surface roughness based on correlation pattern in Figure 6C for class 1 (a), class 2 (b), and class 3 (c).

\section{ACKNOWLEDGMENT}

The author thanks to anonymous reviewers for improving the clarity of the paper. The Sentinel-1A SAR and DEM SRTM $30 \mathrm{~m}$ data used in this study were provided by Alaska Satellite Facility (ASF) under https://vertex.daac.asf.alaska.edu/ and USGSEarth Explorer under https://earthexplorer.usgs.gov/, respectively.

\section{REFERENCES}

Hajnsek, I. (2001), Inversion of Surface Parameters Using polarimetric SAR, doctoral dissertation, Fakultät der Friedrich-Schiller-Universität Jena.

Miranda, N., and Meadows, P. J. (2015), Radiometric Calibration of S-1 Level-1 Products Generated by the S-1 IPF,
Technical note, European Space Agency (ESA).

Saepuloh, A., Susanto, A., Sumintadireja, P., and Suparka, E. (2015), Characterizing Surface Manifestation of Geothermal System under Torrid Zone using Synthetic Aperture Radar (SAR) Data, Proceedings of World Geothermal Congress 2015, Melbourne.

Saepuloh , A., Koike, K., Heriawan, M. N., and Kubo, T. (2016), Quantifying Surface Roughness to Detect Geothermal Manifestations from Polarimetric Synthetic Aperture Radar (PolSAR) Data. Proceedings of the $41^{\text {th }}$ Annual Stanford Geothermal Workshop, California. 